Indian J Anim Health (2021), 60(2): 222-230

DOI: https://doi.org/10.36062/ijah.2021.05121

\title{
Dietary supplementation of fish meal on growth and reproductive performances of black molly, Poecilia sphenops (Valenciennes)
}

\author{
S. O. Khairnar ${ }^{1 *}$ and V. I. Kaur ${ }^{1}$ \\ ${ }^{1}$ Department of Aquaculture, College of Fisheries, Guru Angad Dev Veterinary and Animal Sciences \\ University, Ludhiana- 141 004, Punjab, India
}

\begin{abstract}
The present study was designed to investigate the effect of dietary supplementation of fish meal on the survival, growth and reproductive performances of Poecilia sphenops $(0.58 \pm 0.01 \mathrm{~g}$ and $2.25 \pm 0.05 \mathrm{~cm})$ in fiberglass rectangular tanks $\left(1 \mathrm{~m}^{3}\right)$ for 180 days. Total 135 individuals were randomly distributed according to their sex ratio 1:2 (male: female) in three treatments (basal diet: BD-without fish meal; FM10: $10 \%$ fish meal and FM20: $20 \%$ fish meal) in triplicate. Fishes were fed with the experimental diets upto satiation. The total length gain, net weight gain, specific growth rate increased, while food conversion ratio and protein efficiency ratio reduced with dietary inclusion of fish meal. The reproductive performances like ovarian mass, absolute fecundity, gonado-somatic index, relative fecundity, mean fry production per female and fry survival rate were significantly higher in FM20 as compared to FM10 and BD. The findings of the study revealed that the $20 \%$ dietary inclusion of fish meal improves the growth and reproductive performances in black molly.
\end{abstract}

Key words: Broodstock nutrition, Fish meal, Formulated feed, Growth, Molly

\section{INTRODUCTION}

Ornamental fish keeping is one of the oldest hobbies in the world and next only to photography in popularity (Kaur et al., 2016). In recent times, ornamental fish keeping has become a necessity from luxury and is assuming importance among people as a stress reliever. Globally, ornamental fish trade is estimated to be worth more than US\$ 1 billion, whereas growth in the entire industry, including fish feed and accessories, is estimated to be at about US\$ 18-20 billion, with an average annual growth rate of 14 percent (Raja et al., 2019).

In India, the ornamental fish trade generates substantial livelihoods and contributes significantly to the economy. It is concentrated in and around the metropolises of Kolkata, Mumbai and Chennai. Indian waters possess rich diversity of ornamental fishes (>150 spp.), and out of 280 exotic species which have been introduced in the country so far, over 100 species and a similar number of indigenous species are bred successfully in captivity (Swain et al., 2010).
Ornamental fishes are often tiny, peaceful, encompassing attractive colours and suitable for rearing in captivity. Basically, they are of two types, viz., egg-layers (oviparous) and livebearers (ovo-viviparous). Livebearers that belong to the Poeciliidae family are the most popular ornamental fish for breeding (Alderton, 2012). Guppy, Poecilia reticulate; molly, Poecilia sphenops; swordtail, Xiphophorus helleri; platy, Xiphophorus maculatus and mosquito fish, Gambusia affinis are members of this family and are easy to breed. Ideally, poecilids are raised in cemented tanks, outdoors earthen ponds and net cages. Livebearers maintained in captivity prefer to feed on live food organisms coupled with fish meal, skimmed milk powder, rice bran and wheat flour, but this may not offer adequate nutrients to broodstock fish (Coad, 2017). Due to differences in biological processes, brood fish may have different nutritional needs than young fish.

Broodstock nutrition is one of the most

"Corresponding Author, E mail: sachinkhairnar5983@gmail.com 
poorly understood and researched areas in aquaculture (Berlinsky et al., 2020). Since, research on broodstock nutrition is limited and relatively expensive, it is generally regarded as high risk (Izquierdo et al., 2001). Furthermore, to study the effect of broodstock nutrition on egg composition, the feeding period needs to be variable; this makes it difficult to carry out lengthy studies (Izquierdo et al., 2001). The broodstock diet composed of proteins, lipids and fatty acids is identified as one of the major factors that determine the success of reproduction and survival of young ones (Swain et al., 2010). Several reports on broodstock nutrition have shown a positive relationship between maternal nutrition and reproductive performance (Chong et al., 2004; Kithsiri et al., 2010; Pandey et al., 2016).

Fish meal is a nutrient-rich and high-protein feed ingredient that is trusted as a reliable source of protein due to its nutritional quality and its ability to satisfy the nutritional needs of broodstock (Jannathulla et al., 2019). The highquality fish meal normally contains between $60 \%$ and $72 \%$ crude protein by weight (Deborah et al., 2011). Optimum dietary protein levels for ornamental fishes depend on species, age, feeding level, quality of diet ingredients, protein-energy ratio and diet composition (NRC, 2011). The earlier investigations on livebearers have reported that fish fed with 25$40 \%$ optimal level of dietary protein achieved the highest mean body weight, ovary weight, gonado-somatic index (GSI) and the number of yolky oocytes, suggesting that broodstock nutrition plays a vital role in governing egg production and larval survival, and resulting in better reproductive performances (Mohanta et al., 2016; Pandey et al., 2016; Uribe et al., 2018). The livebearers bred easily in captivity and view of this, breeders do not pay much attention to provide the fish with a nutritionally balanced diet. The nutritionally imbalanced feed may lead to problems like small brood size, production of inferior quality fry leading to a low survival rate. In the present study, we hypothesized dietary supplementation of fish meal on survival, growth and reproductive potential of black molly. Therefore, an attempt was made to evaluate the effects of dietary supplementation of fish meal on survival, growth and reproductive potential of black molly, Poecilia sphenops (Valenciennes).

\section{MATERIALS AND METHODS}

Experimental site: The trial was conducted over a period of 180 days in outdoor fiberglassreinforced plastic $(\mathrm{FRP})$ pools $(1.5 \mathrm{~m} \times 1 \mathrm{~m} \times 0.75 \mathrm{~m})$ with water holding capacity of approximately 1.0 $\mathrm{m}^{3}$ at the fish farm of College of Fisheries, Guru Angad Dev Veterinary and Animal Sciences University (GADVASU), Ludhiana, Punjab $\left(30^{\circ} 54^{\prime} 21.5^{\prime \prime} \mathrm{N}\right.$ and $\left.75^{\circ} 48^{\prime} 04.7^{\prime \prime} \mathrm{E}\right)$.

Experimental design: Healthy, active and equal-sized fry of black molly, Poecilia sphenops were procured from the local aquarium fish shop of Ludhiana. Fish were acclimatized for 15 days under indoor conditions and fed ad libitum twice a day with a commercial diet. The experiment consisted of 3 treatments including basal diet (BD, $0 \%$ fish meal), FM10 and FM20 with dietary supplementation levels of the fish meal at the rate of $10 \%$ and $20 \%$ respectively in triplicate (Table 1). Before stocking, fishes were weighed and measured individually and transferred at the rate of 15 nos. advanced fry of black molly (1 male: 2 female) sex ratio to each tank.

Experimental diet: The three experimental diets namely with the different levels of dietary protein with increasing levels of fish meal (FM10-10\% and FM20-20\%) including control (basal diet, BD- 0\%) were formulated using major protein sources like fish meal, mustard meal and soybean meal (Table 1). Total protein and total carbohydrate input were distributed as per the Pearson square method (de Silva and Anderson, 1995). The proximate composition of formulated diets was analyzed by following the standard methods of AOAC (2005) (Table 1). The variation in protein content in experimental diets was mainly due to incorporating different 
Table 1. Formulation and proximate composition (\%) of experimental diets for black molly during 6 months trial

\begin{tabular}{llll}
\hline Ingredient composition & \multicolumn{3}{c}{ Experimental diets } \\
\cline { 2 - 4 } (\% dry matter basis) & BD & FM10 & FM20 \\
\hline Fish meal & 0.00 & 10.00 & 20.00 \\
Rice bran & 33.00 & 30.50 & 28.00 \\
Mustard meal & 40.00 & 35.00 & 30.00 \\
Soybean meal & 11.50 & 11.50 & 11.50 \\
Wheat flour & 11.50 & 9.00 & 6.50 \\
Soy oil & 1.50 & 1.50 & 1.50 \\
Lysine & 0.50 & 0.50 & 0.50 \\
Methionine & 0.50 & 0.50 & 0.50 \\
Vitamin - mineral mixture & 1.50 & 1.50 & 1.50 \\
\hline Proximate composition & & & 9.21 \\
(\% dry matter basis) & & & 30.67 \\
Moisture & 10.23 & 9.72 & 6.79 \\
Crude protein & 22.70 & 26.95 & 5.76 \\
Ether extract & 5.23 & 6.53 & 11.11 \\
Total ash & 5.31 & 5.39 & 36.46 \\
Crude fiber & 12.66 & 11.25 & 14.22 \\
Nitrogen free extract & 43.87 & 40.16 & 13.87 \\
Gross energy (kJ/kg) & 13.39 & & \\
\hline Not Ditary tea & & & \\
\hline
\end{tabular}

Note: Dietary treatments with different levels of fish meal: BD (0\% fish meal), FM10 (10\% fish meal) and FM20 (20\% fish meal)

levels of high protein fish meal. Fish were fed to satiation twice a day at 09:00 and 17:00 $\mathrm{h}$ with formulated supplementary diets during the experiment.

Proximate composition: The moisture content was determined by drying samples in an oven at $102^{\circ} \mathrm{C}$ till a constant weight. Crude protein content was determined using an automated Kjeldahl (Kelplus, PELICAN, India). Crude lipid was determined by the ether extraction method using the Soxhlet apparatus (PELICAN, India). Ash content was determined by burning the samples in a muffle furnace (Khera Instruments Pvt. Ltd.) at $550^{\circ} \mathrm{C}$ for $18 \mathrm{hr}$. The crude fiber was determined by Fibra Plus (India). The total carbohydrate content was approximated as the value for $\mathrm{N}$-free extract (NFE), and gross energy (GE) was calculated based on the following formula:

NFE $(\%)=(100 \%)-[(\%$ Protein $)+(\%$ Fat $)+$ $(\%$ Fiber $)+(\%$ Moisture $)+(\%$ Ash $)] \ldots . .($ NRC , 2011).

Gross Energy $(\mathrm{kJ} / \mathrm{kg})=($ Protein $\times 23.6 \mathrm{~kJ} / \mathrm{kg})+$ $($ Fat $\times 39.5 \mathrm{~kJ} / \mathrm{kg})+(\mathrm{NFE} \times 17.2 \mathrm{~kJ} / \mathrm{kg}) \ldots . .(\mathrm{NRC}$, 2011).

Water quality parameters: Throughout the trial, bore-well water was used to fill, exchange, and maintain the water level in the experimental tanks. Moreover, $1 / 4^{\text {th }}$ and $3 / 4^{\text {th }}$ of freshwater were exchanged with experimental tanks weekly and monthly respectively. In accordance with standard procedures, temperature, $\mathrm{pH}$, dissolved oxygen, alkalinity, hardness, ammonia nitrogen and nitrate nitrogen were monitored every two weeks (APHA, 2005). 
Growth performance and feed utilization:

Growth parameters were assessed monthly by recording total body length and body weight. Fishes were kept without food overnight before measuring body weight, and body weights were measured by using an electronic precision balance (Mettler Toledo). At the end of the experiment, fish were harvested from each experimental tank by using a suitable net and rapidly transferred into separate plastic tubs containing water. The fish were dried using a clean and sterile filter paper to remove the excess water before recording the final body weights (FBW). Growth performance and feed utilization were calculated according to the standard formulas (Kithsiri et al., 2010).

Total length gain $(\mathrm{TLG}, \mathrm{cm})=$ final length $(\mathrm{g})$ - initial length $(\mathrm{g})$.

Net weight gain $(\mathrm{NWG}, \mathrm{g})=$ final weight $(\mathrm{g})$ initial weight $(\mathrm{g})$.

Specific growth ratio (SGR, [\% body weight/ day $])=100 \times(\ln [$ final weight $]-\ln$ [initial weight])/feeding days.

Feed consumption $(\mathrm{FC})(\mathrm{g})=$ the amount of feed consumed by each fish during the experimental period.

Feed conversion ratio $(F C R)=$ dry feed intake $(\mathrm{g}) /$ wet-weight gain $(\mathrm{g})$.

Fulton's condition factor $(\mathrm{K})(\%)=100 \times$ (final body weight $[\mathrm{g}] /[\text { total length }]^{3}[\mathrm{~cm}]$ ).

Reproductive studies: Daily observations were made on fish health and fertility. Mature females were picked up and kept in perforated breeding baskets with continuous aeration to collect young ones (come out of the breeding basket through holes) to offer shelter for the new swimming fry and avoid parental cannibalism. After the gestation period, the newly born fry in each tank were collected with a hand net, counted, and kept in separate tanks. The reproductive parameters associated with fry production like relative fecundity, fry production per female and fry survival rate was calculated according to Kithsiri et al. (2010). Three fish from each treatment were sacrificed during the experiment to determine ovary weight, ova volume, ova diameter, fecundity and gonadosomatic index (GSI). The binocular stereoscopic microscope was used to carry out dissections. Excision of the gonad was followed by removal of the oviduct and mesovarium. A digital vernier calliper was used to measure ovarian length, width and height to determine the ovary volume (length $*$ width $*$ height). Absolute fecundity and gonadosomatic index were recorded according to Pandey et al. (2016), and the reproductive parameters were estimated by using the following formula:

GSI $=($ ovary weight $[\mathrm{g}] /$ wet body weight $[\mathrm{g}])$ $\times 100$

Absolute fecundity $=$ number of mature oocytes in the ovary prior to spawning

Relative fecundity $=$ total eggs produced per female/wet body weight

Fry production per female $=($ Total number of fry harvested during the experiment)/ (Number of females)

Fry survival $(\%)=($ Total number of fry survived at the end of the experiment)/ (Total number of fry produce throughout the experiment) $\times 100$

Preparation of tanks for breeding and fry collection: At regular intervals, females were checked for readiness (gravid spot) to release the young ones. Gravid females were placed into breeding tanks (plastic tubs with 40 liter capacity). Breeding tanks were provided with a bunch of monofilament nylon ropes as a shelter for the new swimming fry to prevent parental cannibalism. The fry collected from each replicate breeding tank was put into a separate tank during the breeding period.

Statistical analysis: Statistical analysis was performed with a statistical package (SPSS 20.0 for Windows, SPSS Inc., Richmond, CA, USA). One-way ANOVA was applied to work out the effect of formulated supplementary diets on the growth and reproductive performance of molly $(\mathrm{P} \leq 0.05)$, followed by Duncan's multiple comparison to determine significant differences among the treatments. Differences were considered statistically significant if $\mathrm{P} \leq 0.05$. 


\section{RESULTS}

Water quality parameters: Throughout the study, the water quality parameters recorded similar trends in all the dietary treatments and were found to be slightly affected by the inclusion of dietary fish meal in feed $(\mathrm{p}<0.05)$, except for the temperature, dissolved oxygen and nitrate-nitrogen ( $\mathrm{p}>0.05)$ (Table 2).

Survival and growth performance: The dietary supplementation of the fish meal had a significant $(\mathrm{P}<0.05)$ effect on the survival rate (\%) of fish. Among all treatments, the survival rate was over $80 \%$, but FM20 provided a higher survival rate than the other diets (Table 3). A higher $(\mathrm{P}<0.05)$ growth in terms of total length gain (TLG), net weight gain (NWG) and SGR (3.03, 1.33 and 1.34) was recorded in fish fed with FM20 diet compared to FM10 and BD (Table 3).

Food consumption and feed utilization: Even though each dietary treatment was widely accepted, there were significant differences $(\mathrm{P}<0.05)$ in FC between treatments (Table 3$)$. FCR decreased with increasing protein levels in feed $(\mathrm{P}<0.05)$, indicating greater efficiency of feed utilization at high protein levels, whereas dietary protein supplementation had no significant effect on PER $(\mathrm{P}>0.05)$. In contrast, the Fulton's condition factor $(\mathrm{K})$ showed marked variation, but no significant differences were found between the treatments $(\mathrm{P}>0.05)$.

Reproductive performance and fry production: Fish fed with FM20 diet showed a significant $(\mathrm{P}<0.05)$ increase in ovarian weight, ovarian volume, number of the mature oocytes, oocyte diameter, absolute fecundity and mean GSI (\%) compared to fish fed with FM10 and BD (Table 4). Further, the relative fecundity and fry production per female was significantly $(\mathrm{P}<0.05)$ affected by higher supplementation of fish meal in the FM20 group (Table 4) without showing any significant differences $(\mathrm{P}>0.05)$ in fry survival between the treatments.

\section{DISCUSSION}

This study evaluates the inclusion of dietary fish meal on growth, survival, body composition, and particularly, reproductive performance of black molly, as a model of poecilids fish. During the feeding trials, all the experimental diets were well accepted by the brood fishes. Moreover, all the fish approximately reached sexual maturity and were able to produce fry in the batches as poecilids display fractional spawning behaviour. Water quality parameters were constant for all dietary treatments throughout the trial, which is in accordance with prior studies on livebearers (Chong et al., 2004; Ling et al., 2006).

The dietary protein level influences the body weight in different fish species (Ling et al., 2006; Pandey et al., 2016). Based on the results of this study, lower food conversion ratios at high protein levels are associated with better growth. It has also been shown that better feed conversion correlates with higher growth and reproduction in guppies (Kithsiri et al., 2010) as well as mollies (Pandey et al., 2016). Conversely, the dietary protein supplementation produced less variable results with respect to protein efficiency ratios, which was probably due to the limited growth of poecilids. It is reported that the crude protein content in broodstock diets of livebearer ornamental fish ranges between 25 and $40 \%$ (Mohanta et al., 2016; Pandey et al., 2016; Uribe et al., 2018). Likewise, bestowing to the above recommendation the proximate composition of the experimental diets in the present study indicated that the dietary requirement of molly was fulfilled, as diet FM20 contained optimal levels of protein, lipid and carbohydrate compared to FM10 and BD. The results of the study were in agreement with earlier findings of Pandey et al. (2016) that dietary protein level of $28.8 \%$ is adequate for the growth and reproductive performance of molly, Poecilia sphenops. Furthermore, Chong et al. (2004) reported that the incorporation of 
Table 2. Water quality parameters $(M e a n \pm$ S.E.) in different treatments during trial

\begin{tabular}{llll}
\hline Parameter & \multicolumn{3}{c}{ Experimental diets } \\
\cline { 2 - 4 } & \multicolumn{1}{c}{ BD } & \multicolumn{1}{c}{ FM10 } & FM20 \\
\hline Temperature $\left({ }^{\circ} \mathrm{C}\right)$ & $28.40 \pm 0.39$ & $28.50 \pm 0.32$ & $28.55 \pm 0.42$ \\
pH & $7.76 \mathrm{c} \pm 0.03$ & $7.81^{\mathrm{b}} \pm 0.01$ & $7.88^{\mathrm{a}} \pm 0.01$ \\
Dissolved oxygen $\left(\mathrm{mg} \mathrm{L}^{-1}\right)$ & $5.57 \pm 0.20$ & $5.71 \pm 0.20$ & $5.75 \pm 0.20$ \\
Total hardness $\left(\mathrm{CaCO}_{3} \mathrm{mg} \mathrm{L}^{-1}\right)$ & $158.57^{\mathrm{c}} \pm 1.26$ & $168.57^{\mathrm{b}} \pm 1.45$ & $174.57^{\mathrm{a}} \pm 1.62$ \\
Total alkalinity $\left(\mathrm{CaCO}_{3} \mathrm{mg} \mathrm{L}^{-1}\right)$ & $172.57^{\circ} \pm 3.47$ & $184.57^{\mathrm{b}} \pm 1.73$ & $187.57^{\mathrm{a}} \pm 2.13$ \\
Ammonia-nitrogen $\left(\mathrm{NH}_{3}-\mathrm{N}, \mathrm{mg} \mathrm{L}^{-1}\right)$ & $0.052^{\mathrm{b}} \pm 0.002$ & $0.058^{\mathrm{a}} \pm 0.002$ & $0.059^{\mathrm{a}} \pm 0.002$ \\
Nitrate-nitrogen $\left(\mathrm{NO}_{3}-\mathrm{N}, \mathrm{mg} \mathrm{L}^{-1}\right)$ & $0.045 \pm 0.002$ & $0.044 \pm 0.002$ & $0.048 \pm 0.003$ \\
\hline
\end{tabular}

Note: Values (mean \pm standard error) with different superscripts in a row differ significantly $(\mathrm{P}<0.05)$

Table 3. Effect of dietary inclusion of fish meal on growth performance, food consumption and feed utilization of black molly in different treatments

\begin{tabular}{llll}
\hline Parameters /Treatments & BD & FM10 & FM20 \\
\hline Initial total length $(\mathrm{cm})$ & $2.25 \pm 0.06$ & $2.30 \pm 0.06$ & $2.20 \pm 0 . .04$ \\
Final total length $(\mathrm{cm})$ & $4.46^{\mathrm{c}} \pm 0.22$ & $4.91^{\mathrm{b}} \pm 0.11$ & $5.23^{\mathrm{a}} \pm 0.20$ \\
Total length gain (TLG) & $2.21 \pm 0.17$ & $2.61 \pm 0.19$ & $3.03 \pm 0.14$ \\
Initial body weight $(\mathrm{g})$ & $0.59 \pm 0.02$ & $0.58 \pm 0.01$ & $0.57 \pm 0.02$ \\
Final body weight $(\mathrm{g})$ & $1.55^{\mathrm{c}} \pm 0.03$ & $1.78^{\mathrm{b}} \pm 0.06$ & $1.90^{\mathrm{a}} \pm 0.02$ \\
Net weight gain $(\mathrm{g})$ & $0.96^{\mathrm{c}} \pm 0.06$ & $1.20^{\mathrm{b}} \pm 0.04$ & $1.33^{\mathrm{a}} \pm 0.06$ \\
SGR $(\%)$ & $1.17^{\mathrm{c}} \pm 0.02$ & $1.27^{\mathrm{b}} \pm 0.04$ & $1.34^{\mathrm{a}} \pm 0.02$ \\
PER & $0.06 \pm 0.01$ & $0.05 \pm 0.02$ & $0.05 \pm 0.02$ \\
FC $(\mathrm{g})$ & $6.23^{\mathrm{c}} \pm 0.18$ & $5.92^{\mathrm{b}} \pm 0.12$ & $5.51^{\mathrm{a}} \pm 0.23$ \\
FCR & $4.58^{\mathrm{c}} \pm 0.02$ & $3.70^{\mathrm{b}} \pm 0.03$ & $3.18^{\mathrm{a}} \pm 0.02$ \\
Fulton's condition factor $(\mathrm{K})(\%)$ & $1.31^{ \pm} \pm 0.18$ & $1.27 \pm 0.14$ & $1.19^{\mathrm{a}} \pm 0.14$ \\
Broodstock survival $(\%)$ & $84.44^{\mathrm{a}} \pm 0.22$ & $91.11^{\mathrm{b}} \pm 0.59$ & $95.55^{\mathrm{c}} \pm 0.38$ \\
\hline
\end{tabular}

Note: Values are the means \pm standard deviation of the triplicate samples. Means without letter are not significantly different. Letters a, b and c indicate significant differences in treatments, according to Duncan's multiple range tests $(\mathrm{P}<0.05)$.

Table 4. Effect of dietary inclusion of fish meal on reproductive performance and fry production of black molly in different treatments

\begin{tabular}{llll}
\hline & \multicolumn{3}{c}{ Experimental diets } \\
\cline { 2 - 4 } Reproductive parameters & \multicolumn{1}{c}{ BD } & \multicolumn{1}{c}{ FM10 } & \multicolumn{1}{c}{ FM20 } \\
\hline GSI $(\%)$ & $31.61^{\mathrm{a}} \pm 0.47$ & $32.02^{\mathrm{a}} \pm 0.42$ & $34.75^{\mathrm{b}} \pm 0.58$ \\
Absolute fecundity & $9.50^{\mathrm{a}} \pm 0.35$ & $11.66^{\mathrm{b}} \pm 0.17$ & $13.47^{\mathrm{c}} \pm 0.52$ \\
Relative fecundity & $61.53^{\mathrm{a}} \pm 1.31$ & $67.69^{\mathrm{b}} \pm 0.94$ & $71.02^{\mathrm{c}} \pm 0.83$ \\
Oocyte diameter $(\mathrm{mm})$ & $3.66^{\mathrm{a}} \pm 0.05$ & $3.83^{\mathrm{b}} \pm 0.08$ & $4.12^{\mathrm{c}} \pm 0.12$ \\
Ovarian volume $\left(\mathrm{mm}^{3}\right)$ & $956.43^{\mathrm{a}} \pm 8.17$ & $1183.32^{\mathrm{b}} \pm 5.56$ & $1348.40^{\mathrm{c}} \pm 6.38$ \\
Ovarian weight $(\mathrm{g})$ & $0.49^{\mathrm{a}} \pm 0.02$ & $0.57^{\mathrm{b}} \pm 0.03$ & $0.66^{\mathrm{c}} \pm 0.03$ \\
Fry production/female (nos.) & $30.15^{\mathrm{a}} \pm 0.45$ & $39.26^{\mathrm{b}} \pm 0.75$ & $46.87^{\mathrm{c}} \pm 0.71$ \\
Fry survival rate $(\%)$ & $90.84 \pm 4.73$ & $92.36^{\mathrm{b}} \pm 5.45$ & $93.28^{\mathrm{c}} \pm 4.65$ \\
\hline
\end{tabular}

Note: Values are the means \pm standard deviation of the triplicate samples. Means without letter are not significantly different. Letters a, b and c indicate significant differences in treatments, according to Duncan's multiple range tests $(\mathrm{P}<0.05)$. 
fish meal in the diet of ornamental broodstock influenced the growth and reproductive performance. In the present study, the dietary inclusion of $10-20 \%$ fish meal established a linear relationship with the growth and reproductive performances of black molly (Fig.1 and 2). Chong et al. (2004) reported that incorporation of fish meal in broodstock diet up to $20 \%$ enhanced growth and reproductive performance of ornamental livebearer fish (Sword tail, Xiphophorus helleri).

In the present trial, the growth indices implied that high quality protein diet favoured all the growth parameters of the test fish in FM20. However, the fish fed with a basal diet demonstrated a lack of sufficient nutrients to support growth. In order to compensate, there must be sufficient bioavailable nutrients in the fish diet (Ling et al., 2006). According to James and Sampath (2003), a portion of digested protein is used as energy for maintenance and routine metabolism, and the remainder is used for the growth of somatic and gonad tissues. Thus, the reason for slow growth in fish fed with BD and FM10 diets can be attributed to a lack of protein remaining to be converted to flesh or gonad tissues since a large portion of the consumed protein might have gone to maintenance.

In the present study, the slower growth rate of black molly before and during breeding may be due to the greater allocation of assimilated energy to ovary development and fry production (Kithsiri et al., 2010; Bairwa et al., 2017). Furthermore, the fish fed with higher levels of dietary protein showed higher ovary weight, higher fry production and GSI in female relative to the fish fed with the lower levels of dietary protein, indicating better ovarian maturation and oocyte development in black

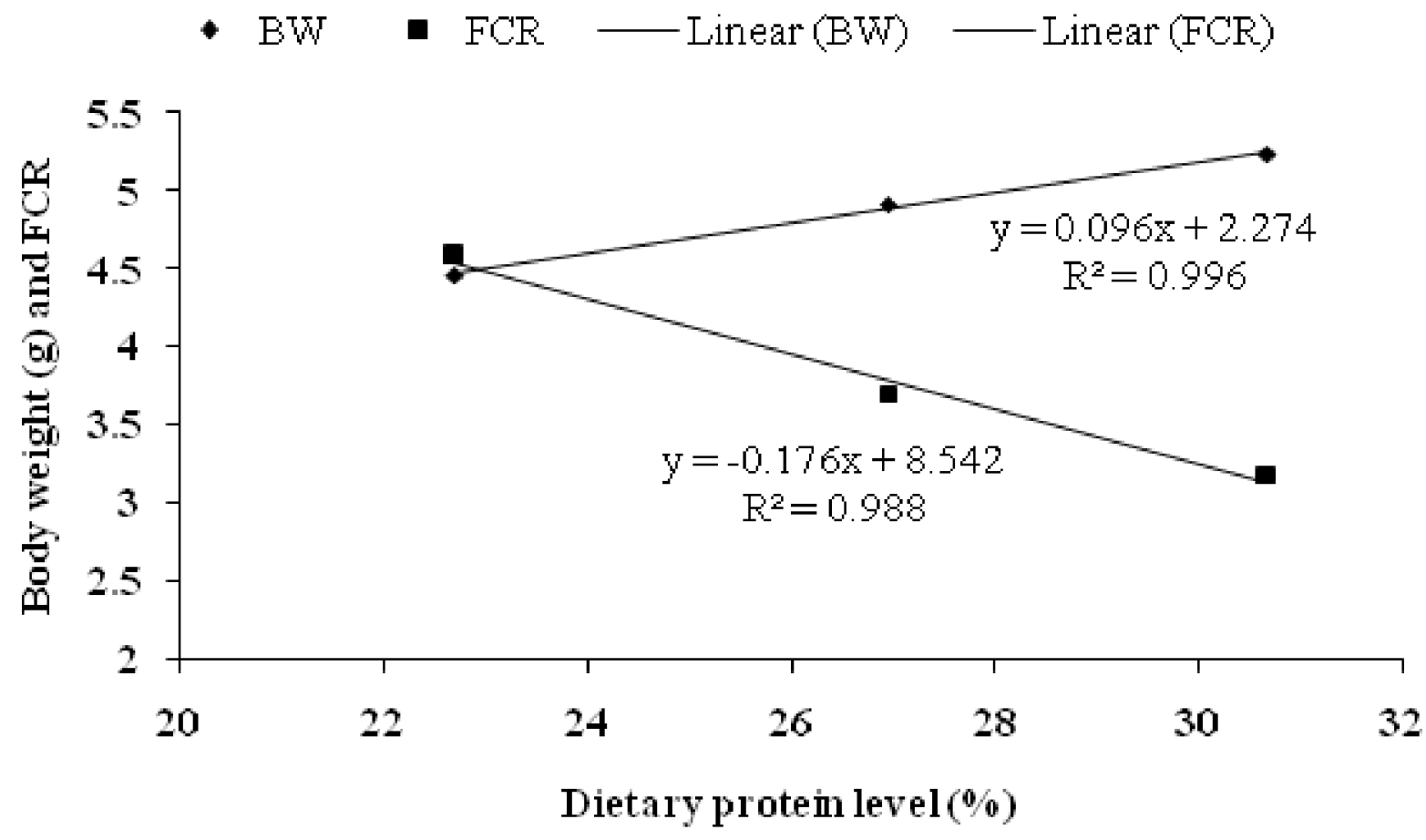

Fig. 1. Linear relationship between dietary protein level in experimental diets vs. body weight and FCR of black molly 


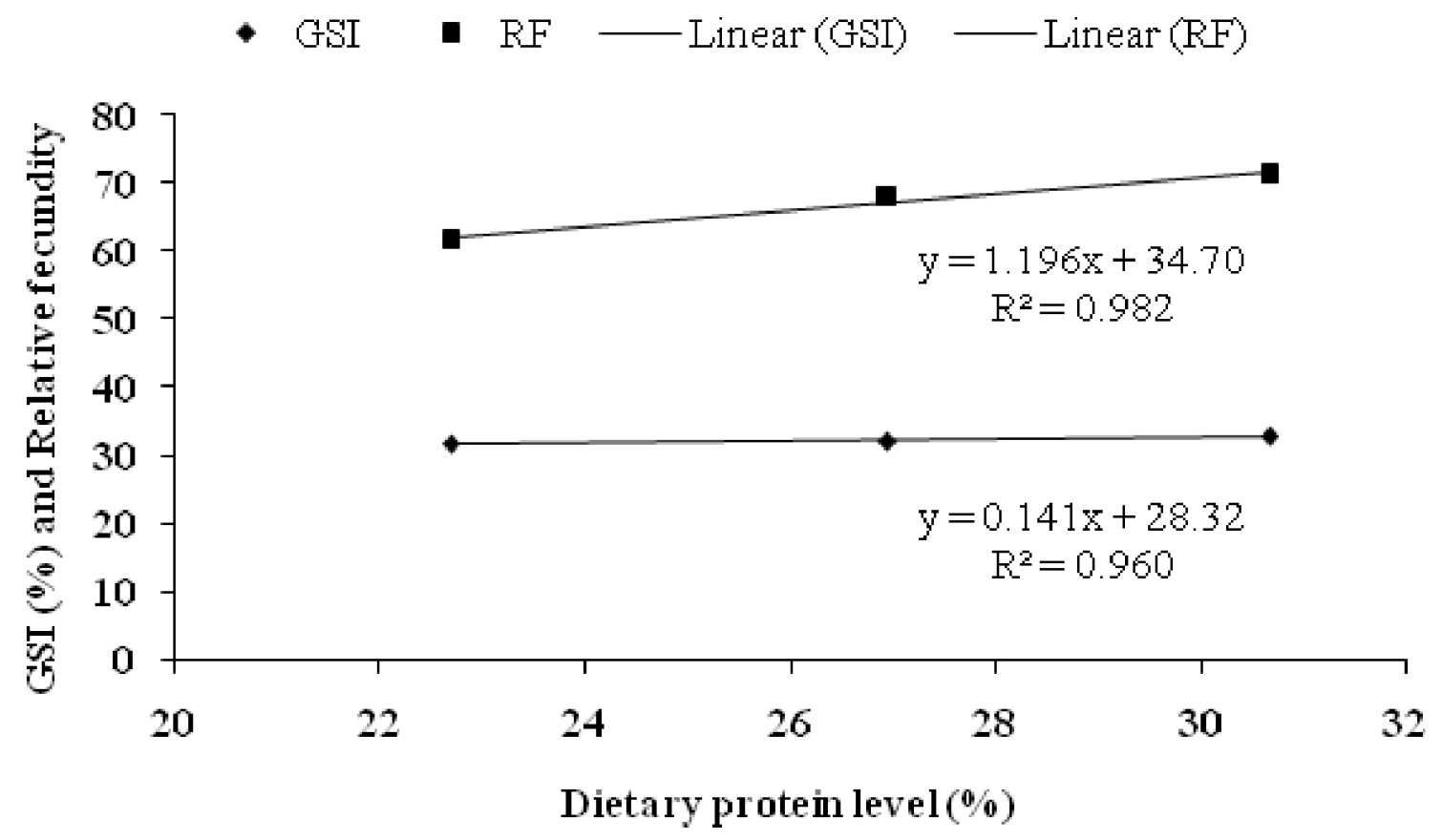

Fig. 2. Linear relationship between dietary protein level in experimental diets vs. GSI and relative fecundity of black molly

molly owing to the presence of $30.67 \%$ crude protein and $1.79 \%$ crude lipid in the FM20 diet. This finding is in line with earlier studies that suggested diets with $25-40 \%$ protein levels were best for growth development, since they resulted in the highest average ovary weight and the largest average number of yolky oocytes in the ovary of poecilids (Kithsiri et al., 2010; Pandey et al., 2016). The reproductive performance and optimum growth rates in broodstock are positively correlated, as many of these factors contribute to earlier oocyte maturation, a higher rate of vitellogenesis, better spawning performances and larger eggs (Reading et al., 2018). Oocyte maturation involves the transportation and acceleration of protein and lipid in the oocytes ( $\mathrm{Gu}$ et al., 2015). The effects of supplemental diets on fry growth have been investigated extensively but the results remain inconclusive. However, the lowest number of fry in BD didn't compromise with the quality of the young fry in mollies. Hence, the present study discloses that there was a significant influence on fecundity, probably due to feeding with varying protein levels.

In conclusion, the diet containing $20 \%$ fish meal (dietary protein: $30.67 \%$ and lipid: $6.79 \%$ ) demonstrated better growth and reproductive performance of female molly compared to the other diets. These results provide a novel insight into the potential utilization of fish meal in poecilids. However, considering the availability of quality fish meal in the market and its economic aspects in aquafeeds, further studies can be conducted on the same lines by incorporating higher levels of dietary fish meal.

Conflict of interest: Authors have no conflict of interest in this study.

\section{ACKNOWLEDGEMENT}

The authors are thankful to the Dean, College of Fisheries, Guru Angad Dev Veterinary and Animal Sciences University, Ludhiana, Punjab for providing the necessary facilities and financial support for experimenting. 


\section{REFERENCES}

Alderton D, 2012. Livebearers: understanding guppies, mollies, swordtails and others, Irwin, California, BowTie Press, pp 144

AOAC, 2005. Official Methods of Analysis. $18^{\text {th }}$ edn., Association of Official Analytical Chemists. Washington, DC, USA

APHA, 2005. Standard Methods for the Examination of Water and Wastewater. $21^{\text {st }}$ edn., APHA-AWWAWPCF, Washington DC, USA, pp 1015

Bairwa MK, Saharan N, Dube K, Tiwari VK and Pani PK, 2017. Effect of LED light spectra on reproductive performance of koi carp (Cyprinus carpio). Indian J Anim Res, 51(6): 1012-1018, doi: 10.18805/ijar.v0iOF.8452

Berlinsky DL, Kenter LW, Reading BJ and Goetz FW, 2020. Regulating reproductive cycles for captive spawning. Fish Physiol, 38: 1-52, doi: 10.1016/ bs.fp.2020.09.001

Chong AS, Ishak SD, Osman Z and Hashim R, 2004. Effect of dietary protein levels on the reproductive performance of female swordtails Xiphophorus helleri (Poeciliidae). Aquaculture, 234(1-4): 381392, doi: 10.1016/j.aquaculture.2003.12.003

Coad BW, 2017. Review of the livebearer fishes of Iran (Family Poeciliidae). Iranian J Ichthyol, 4: 305330, doi: 10.22034/iji.v4i4.232

de Silva SS and Anderson TA, 1995. Fish nutrition in aquaculture. $1^{\text {st }}$ edn., London, Chapman Hall, pp 319

Deborah PT, Divya VV, Ulaganathan P, Balamurugan V and Umamaheswari S, 2011. Replacing fish meal with earthworm and mushroom meals in practical diets of Labeo rohita and Hemigrammus caudovittatus fingerlings. Indian J Anim Res, 45(2): 115-119

Gu L, Liu H, Gu X, Boots C, Moley KH et al., 2015. Metabolic control of oocyte development: linking maternal nutrition and reproductive outcomes. Cell Mol Life Sci, 72(2): 251-271, doi: 10.1007/ s00018-014-1739-4

Izquierdo MS, Fernandez-Palacios $\mathrm{H}$ and Tacon AGJ, 2001. Effect of broodstock nutrition on reproductive performance of fish. Aquaculture, 197(s 1-4): 25 42, doi: 10.1016/S0044-8486(01)00581-6

James R and Sampath K, 2003. Effects of meal frequency on growth and reproduction in the ornamental red swordtail, Xiphophorus helleri. Israel J AquacultBamidgeh, 55(3): 197-207

Jannathulla R, Rajaram V, Kalanjiam R, Ambasankar K, Muralidhar M et al., 2019. Fishmeal availability in the scenarios of climate change: Inevitability of fish meal replacement in aquafeeds and approaches for the utilization of plant protein sources. Aquac Res, 50(12): 3493-3506, doi: 10.1111/are.14324

Kaur S, Kaur VI, Holeyappa SA and Khairnar SO, 2016. Effect of dietary supplementation of synthetic and natural $\beta$-carotene on survival, growth and pigmentation in freshwater ornamental koi (Cyprinus carpio L.) carp. Indian J Anim Nutr, 33(4): 448-455, doi: 10.5958/2231-6744.2016. 00079.7

Kithsiri HMP, Sharma P, Zaidi SGS, Pal AK and Venkateshwarlu G, 2010. Growth and reproductive performance of female guppy, Poecilia reticulata (Peters) fed diets with different nutrient levels. Indian J Fish, 57(1): 65-71

Ling S, Hashim R, Kolkovski S and Chong AS, 2006. Effect of varying dietary lipid and protein levels on growth and reproductive performance of female swordtails Xiphophorus helleri (Poeciliidae). Aquac Res, 37(13): 1267-1275, doi: 10.1111/j.13652109.2006.01554.x

Mohanta KN, Subramanian S and Korikanthimath VS, 2016. Effect of different animal protein sources on growth and nutrient utilization of guppy, Poecilia reticulata fingerlings. Proc Zool Soc, 69(1): 96103, doi: 10.1007/s12595-014-0130-7

National Research Council (NRC), 2011. Nutrient requirements of fish and shrimp. Washington DC, National Academic Press, doi: 10.17226/13039

Pandey A, Kaur VI, Srivastava A, Datta SN and Singh A, 2016. Effect of formulated feeds with different nutrient levels on growth and reproductive performance of molly, Poecilia sphenops (Valenciennes). Anim Nutr Feed Technol, 16(1): 61-69, doi: 10.5958/0974-181X.2016.00006.8

Raja K, Aanand P, Padmavathy S and Sampathkumar JS, 2019. Present and future market trends of Indian ornamental fish sector. Int J Fish Aquat Stud, 7(2): 6-15

Reading BJ, Andersen LK, Ryu YW, Mushirobira Y, Todo T et al., 2018. Oogenesis and egg quality in finfish: yolk formation and other factors influencing female fertility. Fishes, 3(4): 45, doi: 10.3390/fishes3040045

Swain SK, Sarangi N and Ayyappan S, 2010. Ornamental fish farming, Indian Council of Agricultural Research, New Delhi, India, pp 145

Uribe EA, Archundia MPF and Luna-Figueroa J, 2018. The effect of live food on the coloration and growth in guppy fish, Poecilia reticulate. Agric Sci, 9(2): 171-179, doi: 10.4236/as.2018.92013

Received 23.05.21, Accepted - 27.07.2021, Published-02.09.2021 (Online), 01.12.2021 (Print)

Section Editor: Prof. S. K. Das, Associate Editor 